\title{
Profitability Attributes and the level of Disclosure: A Study on Listed Pharmaceutical Companies of Bangladesh
}

\author{
Md. Shakawat Hossain
}

Assistant Professor, Department of Accounting \& Information Systems, Jagannath University, BANGLADESH

\begin{abstract}
The objective of the study is to examine empirically the likely association between the level of disclosure and various profitability attributes. In order to identify the determinants of disclosure, regression analysis, multiple linear regression techniques have been used. The analysis and discussion of the study have already established the fact that the extent of disclosure varies across pharmaceutical company and across various sections of pharmaceutical company annual reports. The paper has been prepared having in minded the significant corporate attributes that are significantly associated with the level of disclosure.
\end{abstract}

Key words: Disclosure Score, Profitability, Pharmaceutical Company, Bangladesh

JEL Classification Code: M41

\section{INTRODUCTION}

The destination of this study is to examine the association between well-known corporate attributes profitability and the level of disclosure in corporate annual reports of pharmaceutical sector of Bangladesh. The corporate attributes considered are profitability proxied by EPS, ROA, ROE, net profit margin (NPM), and gross revenue (GR). The Unweighted Disclosure Index (UDI) has been calculated for each of the firms studied and these have been used as the dependent variables. UDI has been arrived at by aggregating the number of disclosed items in each corporate annual report by using a dichotomous approach where a pharmaceutical company will be awarded ' 1 ' for disclosing an item and if not, has been awarded ' 0 ', so that the total number of items disclosed in the annual report becomes equal to the total score to be obtained by the pharmaceutical company.

\section{Disclosure Studies of some Researchers and Their Results about RELATIONSHIP}

There are researchers who have tried to establish the relationship between a number of corporate attributes and the level of disclosure in corporate annual report. However, some of the corporate attributes have shown significant relationship with the level of disclosure while other researchers did not find any relationship between them. The following Table 1 identifies the corporate attributes used by these researchers and indicates whether 
relationships have been proved with respect to disclosure in a particular country or countries: -

Table 1

Disclosure Studies, independent variables and their results

\begin{tabular}{|c|c|c|c|c|}
\hline $\begin{array}{c}\text { RESEAR } \\
\text { CHERS }\end{array}$ & $\begin{array}{l}\text { COUN } \\
\text { TRY }\end{array}$ & $\begin{array}{l}\text { INDEPENDENT } \\
\text { VARIABLES }\end{array}$ & $\begin{array}{c}\text { SIGNIFICANT } \\
\text { RELATIONSHIP } \\
\end{array}$ & $\begin{array}{c}\text { NO SIGNIFICANT } \\
\text { RELATIONSHIP } \\
\end{array}$ \\
\hline $\begin{array}{l}\text { Ahmed } \\
(2009)\end{array}$ & $\begin{array}{l}\frac{\mathscr{q}}{d}=1 \\
\frac{\pi}{00} \\
\vec{\pi} \\
\infty\end{array}$ & \begin{tabular}{|l} 
1) EPS \\
2) ROI \\
3) ROA \\
4) Net Profit Margin \\
(NPM) \\
\end{tabular} & $\begin{array}{l}\text { Significant relationship } \\
\text { between ROA and the } \\
\text { extent of disclosure }\end{array}$ & $\begin{array}{l}\text { No significant } \\
\text { association between } \\
\text { ROI, EPS, NPM and } \\
\text { the extent of } \\
\text { disclosure }\end{array}$ \\
\hline $\begin{array}{l}\text { Inchausti } \\
(1997)\end{array}$ & $\begin{array}{l}\text { ॠ } \\
\text { के }\end{array}$ & \begin{tabular}{|l|} 
1) Size (as measured by \\
assets), \\
2) Multiple stock \\
exchange listing, \\
3) Profitability (ROA \\
and ROE), \\
4) Leverage (total \\
liability /equity), \\
5) Audit firm size, \\
6) Industry, and \\
7) Dividend pay out \\
\end{tabular} & \begin{tabular}{|l|} 
Significant relationship \\
between assets size, \\
multiple stock exchange \\
listing, ROA, Audit firm \\
size and the extent of \\
disclosure
\end{tabular} & $\begin{array}{l}\text { No significant } \\
\text { association between } \\
\text { ROE, leverage (total } \\
\text { liability / equity), } \\
\text { industry dividend } \\
\text { pay out and the } \\
\text { extent of disclosure }\end{array}$ \\
\hline $\begin{array}{l}\text { Raffourni } \\
\text { er (1995) }\end{array}$ & 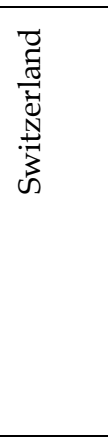 & \begin{tabular}{|l|} 
1) Company size (as \\
measured by assets), \\
2) Leverage, \\
3) Profitability, \\
4) Ownership structure, \\
5) Internationality of the \\
companies, \\
6) Auditor's size, \\
7) Percentage of assets \\
(assets-in-place), and \\
8) Industry type \\
\end{tabular} & $\begin{array}{l}\text { Significant relationship } \\
\text { between assets size, } \\
\text { auditor's size, ROA and } \\
\text { the extent of disclosure }\end{array}$ & $\begin{array}{l}\text { No significant } \\
\text { association between } \\
\text { ownership structure, } \\
\text { assets-in-place, } \\
\text { industry type, } \\
\text { leverage and the } \\
\text { extent of disclosure }\end{array}$ \\
\hline $\begin{array}{l}\text { Wallace } \\
\text { and Nasen } \\
(1995)\end{array}$ & 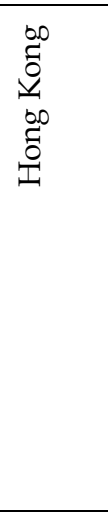 & \begin{tabular}{|l|} 
1) Profit margin, \\
2) Earnings return, \\
3) Liquidity ratios, \\
4) Debt-equity ratios \\
(leverage), \\
5) Farm size (total \\
assets, sales and \\
capitalized market \\
value), \\
6) Market capitalization, \\
7) Scope of business \\
operations, and \\
8) Audit size influence \\
\end{tabular} & \begin{tabular}{|l|} 
Significant relationship \\
between profit margin, \\
total assets, scope of \\
business operations size, \\
audit size influence and \\
the extent of disclosure
\end{tabular} & $\begin{array}{l}\text { No significant } \\
\text { association between } \\
\text { market capitalization, } \\
\text { liquidity ratios, ROE } \\
\text { and the extent of } \\
\text { disclosure }\end{array}$ \\
\hline
\end{tabular}




\begin{tabular}{|c|c|c|c|c|}
\hline $\begin{array}{l}\text { Wallace } \\
(1987)\end{array}$ & 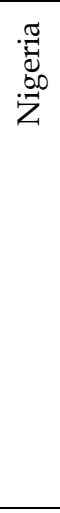 & $\begin{array}{l}\text { 1) Firm size measured } \\
\text { by sales, } \\
\text { 2) Firm size measured } \\
\text { by assets, } \\
\text { 3) Number of } \\
\text { shareholders, } \\
\text { 4) Profitability, } \\
\text { 5) Liquidity, } \\
\text { 6) Industry type, } \\
\text { 7) Multi-nationality of } \\
\text { the firm and } \\
\text { 8) Country of origin of } \\
\text { multinationals }\end{array}$ & $\begin{array}{l}\text { Significant relationship } \\
\text { between total assets, and } \\
\text { multi-nationality and } \\
\text { the extent of disclosure }\end{array}$ & $\begin{array}{l}\text { No significant } \\
\text { association between } \\
\text { liquidity, profitability } \\
\text { (rate of return and } \\
\text { earnings margin), } \\
\text { annual sales, number } \\
\text { of shareholders, } \\
\text { industry type and } \\
\text { origin of multi- } \\
\text { nationals and the } \\
\text { extent of disclosure }\end{array}$ \\
\hline $\begin{array}{l}\text { Belkaoui } \\
\text { and Kahl } \\
(1978)\end{array}$ & $\frac{\pi}{\tilde{\Xi}}$ & $\begin{array}{l}\text { 1) Size of the firm (as } \\
\text { measured by sales), } \\
\text { 2) Profitability, } \\
\text { 3) Liquidity, } \\
\text { 4) Capitalization ratio } \\
\text { and } \\
\text { 5) Industry type }\end{array}$ & \begin{tabular}{|l|} 
Significant relationship \\
between size of the firm, \\
industry type, \\
profitability and \\
capitalization ratio and \\
the extent of disclosure
\end{tabular} & $\begin{array}{l}\text { No significant } \\
\text { association between } \\
\text { liquidity and the } \\
\text { extent of disclosure }\end{array}$ \\
\hline
\end{tabular}

\section{HYPOTHESES FOR THE STUDY}

The goal of this chapter is to examine the association between the extent of information disclosure in published annual reports of and a number of corporate profitability attributes. The anticipated association is examined by the following null hypothesis:

$H_{0}$ : There is no significant association between a number of profitability attributes [viz., EPS, ROA, ROE, Net Profit Margin (NPM), and Gross Revenue (GR)] and the level of disclosure.

The multiple linear regression technique has been used to test the two alternative hypotheses.

\section{The Dependent Variables, Independent Variables and Hypotheses}

The dependent variable used in this study is UDI and the disclosure index has been calculated for each of the pharmaceutical company studied. The independent variables used in this study have taken into the account previous studies undertaken by other researchers. These researchers have tested these variables in respect of both developed and developing countries. The profitability attributes considered are proxied by EPS, ROA, ROE, NPM and GR.

\section{Profitability}

Pharmaceutical companies having higher profitability may disclose more information in their corporate annual reports than the pharmaceutical companies with lower profitability (or losses) for a number of reasons. If the profitability of a pharmaceutical company is low, management may disclose less information in order to cover up the reasons for losses or lower profits. On the other hand, if profitability is high, management may disclose more detailed information in the corporate annual report in order to experience the comfort of communicating it as it is good news. For profitable pharmaceutical companies if the EPS, 
ROA, ROE, NPM or GR is more than the pharmaceutical company average, the management of a firm has an incentive to communicate more information which is favorable to it as the basis of explanations of good news and is likely to disclose more information in their corporate annual reports as a result.

Profitability was used by a number of researchers as an independent variable for fluctuations in disclosure level. Among these researchers Ahmed (2009); Inchausti (1997); Raffournier (1995); Wallace and Naser (1995) and Wallace (1987) found a positive association between profitability and the extent of disclosure whereas Belkaoui and Kahl (1978) found a negative association between the variables.

In the present study, EPS, ROA, ROE, NPM and GR have been used as the measures of profitability. The following specific hypotheses have been tested regarding profitability:

$H_{(a)}$ : $\quad$ Profitability as measured by EPS does not affect the disclosure score of the sample firms.

$H_{(b)}$ : Pharmaceutical companies with greater ROA disclose financial information to a greater extent than do those pharmaceutical companies with lower ROA.

$H_{(c)}$ : Profitability as measured by ROE does not affect the disclosure score of the pharmaceutical companies.

$H_{(d)}$ : $\quad$ Pharmaceutical companies with higher net profit margin disclose financial information to a greater extent than do those pharmaceutical companies with lower net profit margin ratios.

$H_{(e)}$ : $\quad$ Pharmaceutical companies with greater gross revenue disclose financial information to a greater extent than do those pharmaceutical companies with average gross revenue.

\section{Regressional Studies of Disclosure Score vs. Profitability}

To test whether disclosure level of pharmaceutical companies is affected by profitability, we have taken different measures of profitability such as EPS, ROA, ROE, NPM and GR to regress them with disclosure score. Accordingly we have formulated different null hypotheses.

\section{Regressional Studies between Disclosure Score vs. Earning Per Share}

Table showing the Regressional Studies between Disclosure Score vs. EPS

Table 2

\begin{tabular}{|l|c|c|c|}
\hline Year & $\mathrm{R}^{2}$ & F ratios & Significance Level \\
\hline y_2004 & .054 & .572 & .467 \\
\hline y_2005 & .065 & .690 & .425 \\
\hline y_2006 & .031 & .323 & .582 \\
\hline y_2007 & .063 & .674 & .431 \\
\hline y_2008 & .127 & 1.460 & .255 \\
\hline
\end{tabular}

From the regression result we observe that values of $\mathrm{R}^{2}$ are small and the significance levels of the regression co-efficient are above .05. So, our null hypothesis is accepted which means that profitability as measured by EPS does not affect the disclosure score. 


\section{Regressional Studies between Disclosure Score vs. Return on Assets}

Table showing the Regressional Studies between Disclosure Score vs. ROA Table 3

\begin{tabular}{|l|c|c|c|}
\hline Year & $\mathrm{R}^{2}$ & F ratios & Significance Level \\
\hline y_2004 & .003 & .033 & .859 \\
\hline y_2005 & .000 & .001 & .974 \\
\hline y_2006 & .037 &. .381 & .551 \\
\hline y_2007 & .034 & .357 & .563 \\
\hline y_2008 & .015 & .150 & .707 \\
\hline
\end{tabular}

From the regression result we observe that values of $\mathrm{R}^{2}$ are small and the significance levels of the regression co-efficient are above .05. So, our null hypothesis is accepted which means that profitability as measured by ROA does not affect the disclosure score.

\section{Regressional Studies between Disclosure Score vs. Return on Equity}

Table showing the Regressional Studies between Disclosure Score vs. ROE

Table 4

\begin{tabular}{|l|c|c|c|}
\hline Year & $\mathrm{R}^{2}$ & F ratios & Significance Level \\
\hline y_2004 & .001 & .008 & .930 \\
\hline y_2005 & .001 & .009 & .928 \\
\hline y_2006 & .027 & .274 & .612 \\
\hline y_2007 & .003 & .030 & .866 \\
\hline y_2008 & .007 & .066 & .803 \\
\hline
\end{tabular}

From the regression result we observe that values of $\mathrm{R}^{2}$ are small and the significance levels of the regression co-efficient are above .05. So, our null hypothesis is accepted which means that profitability as measured by ROE does not affect the disclosure score.

\section{Regressional Studies between Disclosure Score vs. Net Profit Margin}

Table showing the Regressional Studies between Disclosure Score vs. NPM

Table 5

\begin{tabular}{|l|c|c|c|}
\hline Year & $\mathrm{R}^{2}$ & F ratios & Significance Level \\
\hline y_2004 & .356 & 5.533 & .040 \\
\hline y_2005 & .204 & 2.561 & .141 \\
\hline y_2006 & .081 & .883 & .370 \\
\hline y_2007 & .338 & 5.096 & .048 \\
\hline y_2008 & .515 & 10.600 & .011 \\
\hline
\end{tabular}

From the regression result we observe that values of $\mathrm{R}^{2}$ are small in case of year 2005 and 2006, and the significance levels of the regression co-efficient are above .05 for the said years. Further, we observe that values of $\mathrm{R}^{2}$ are high in case of year 2004, 2007 and 2008 and the significance levels of the regression co-efficients are below .05 for those years. So, our null hypothesis is rejected which means that profitability as measured by NPM affects the disclosure score. 


\section{Regressional Studies between Disclosure Score vs. Gross ReVenue}

Table showing the Regressional Studies between Disclosure Score vs. GR Table 6

\begin{tabular}{|l|c|c|c|}
\hline Year & $\mathrm{R}^{2}$ & F ratios & Significance Level \\
\hline y_2004 & .039 & .402 & .540 \\
\hline y_2005 & .001 & .013 & .911 \\
\hline y_2006 & .055 & .579 & .464 \\
\hline y_2007 & .000 & .005 & .947 \\
\hline y_2008 & .001 & .005 & .943 \\
\hline
\end{tabular}

From the regression result we observe that values of $\mathrm{R}^{2}$ are small and the significance levels of the regression co-efficient are above .05. So, our null hypothesis is accepted which means that profitability as measured by gross revenues (GR) does not affect the disclosure score.

\section{MULTIPLE REgRESSION MODELS}

Multiple linear regression techniques are used to test two alternative versions of each hypothesis. The model is created using UDI as the dependent variable.

$$
U D I=\alpha+\beta_{1} E P S+\beta_{2} R O A+\beta_{3} R O E+\beta_{4} N P M+\beta_{5} G R+\varepsilon
$$

Where UDI $=\quad$ total score received by each pharmaceutical company under un-weighted disclosure index;

$\alpha=\quad$ the constant, and

$\varepsilon=\quad$ the error term.

\section{Regressional Studies of Disclosure Score vs. Multiple Variables}

The results of the correlation matrix for different years show that some of the independent variables taken in the multiple regression Model are correlated. This shows that there lies multi colinearity problem in the model. To reduce the multi colinearity problem in the model all the variables both dependent and independent have been transferred into LOG. Then multiple regression model has been estimated taking these transform variables.

Table showing the Regressional Studies between Disclosure Score vs. Multiple Variables Table 7

\begin{tabular}{|c|c|c|c|}
\hline Year & $\mathrm{R}^{2}$ & F Ratio & Significance Level \\
\hline 2004 & .675 & 2.496 & .148 \\
\hline 2005 & .512 & 1.260 & .388 \\
\hline 2006 & .389 & .638 & .683 \\
\hline 2007 & .331 & .594 & .708 \\
\hline 2008 & .643 & 2.161 & .188 \\
\hline
\end{tabular}

From the above Table we observe that values of $\mathrm{R}^{2}$, $\mathrm{F}$ ratios and their significance levels. Here, our null hypothesis is accepted which means that profitability attributes as measured by EPS, ROA, ROE, NPM and GR together does not affect the disclosure score. 


\section{INDEPENDENT VARIABLES WITH THEIR LABELS AND ASSOCIATION IN THE REGRESSION}

The description of the five independent variables, their labels and significance levels are presented in the following Table.

Table 8

List of independent variables, their labels and significance levels in the regression

\begin{tabular}{|c|l|l|}
\hline Variable Labels & \multicolumn{1}{|c|}{ Variables } & \multicolumn{1}{c|}{ Significance Levels } \\
\hline EPS & Earning per share & Significance levels are above .05. \\
\hline ROA & Return on assets & Significance levels are above .05. \\
\hline ROE & Return on Equity & Significance levels are above .05. \\
\hline NPM & Net profit margin & Significance levels are below .05. \\
\hline GR & Gross revenue & Significance levels are above .05. \\
\hline
\end{tabular}

\section{Discussion OF THE RESULTS}

The regressions carried out in this paper have some interesting aspects. First, the pharmaceutical companies provide a fair representation of the corporate structure of pharmaceutical sector of Bangladesh. The pharmaceutical companies covered by the firm are manufacturing in nature and listed on the Dhaka Stock Exchange. In this study, unweighted disclosure index is found to be significantly positively influenced by Net Profit Margin (NPM) at minimum 1\% level of significance. The multiple regression results (values of $\mathrm{R}^{2}$ ) variable is also significant at approximately $7 \%$ level at the year 2007 and significant at $8 \%$ level at the years 2007 and 2008. Other variables were insignificant for unweighted model at conventionally acceptable levels.

As already mentioned in the previous section the EPS, ROA, ROE, NPM and GR have been used as the measures of profitability. It is found that profitability is a statistically significant determinant of disclosure across the whole pharmaceutical companies. Though, profitability as measured by EPS, ROA, ROE and GR does not affect the UDI, whereas NPM show $1 \%$ level of significance.

Table 7 summarizes the results of multiple regression analyses and the influence of a range of profitability attributes on disclosure by the pharmaceutical companies. Multiple variables affect the UDI, but it is relatively weaker.

\section{LIMITATIONS AND CONCLUSION}

The study had reported the results of multiple linear regressions to test the association between a number of corporate attributes and the extent of disclosure in corporate annual reports of banking sector in Bangladesh. The results had shown that disclosure levels are associated with some company characteristics. Only two variables those were found to be significant in determining disclosure levels are return on assets and capital adequacy ratio. The return on investment showed significant but relatively weaker association. The other variables were found to be insignificant in explaining disclosure. The result of regression timeliness has revealed significant influence of audit lag on disclosure at 0.008 level in 2003 and in that the multiple independent variables also have shown significant influence at 0.035 level.

This study has reported the results of multiple linear regressions to test the association between a number of profitability attributes and the extent of disclosure in corporate annual reports of pharmaceutical sector in Bangladesh. The extent of disclosure was measured using the un-weighted disclosure index. The results have showed that 
disclosure levels are associated with only one profitability characteristic. Net profit margin, only variable, which was found to be significant in determining disclosure levels. The other variables were found to be insignificant in explaining disclosure.

This study considers the annual reports for five years. Further research can be undertaken to measure the extent of disclosure more longitudinally to determine whether quality of disclosure has improved over time. This study does not consider non-listed or financial companies. Further research can be undertaken taking into consideration both groups of companies (financial and non-financial/ manufacturing). This study concentrates on a particular industry type. Further research can be undertaken based on multi industry type. The number of disclosure items was limited to 144 items. The results may be different if the numbers of items were increased or another set of disclosure items were examined, for example, distinctions made between mandatory items and other bases of disclosure. This study did not cover social responsibility disclosures directly, since it is not a developed area of financial reporting practices in the context of developing countries.

\section{REFERENCES}

Ahmed (2009), "Compliance of Financial Disclosure in the Corporate Annual Reports of Banking Sector of Bangladesh", Published PhD Dissertation. Rajshahi University.

Ahmed and Nicholls (1994), "The Impact of Non-financial Company Characteristics on Mandatory Compliance in Developing Countries: The Case of Bangladesh". The International Journal of Accounting, Vol.29, No. 1, pp. 60-77.

Belkaoui and Kahl (1978) "Corporate Financial Disclosure in Canada" Research Monograph No. 1 (Vancouver: Canadian Certified General Accountants Association)

Hossain (1998) "Disclosure of Financial Information in Developing Countries: A Comparative Study of non-financial Companies in India, Pakistan and Bangladesh", Ph.D. Dissertation, School of Accounting and Finance, Victoria University of Manchester, UK, July 1998.

Inchausti (1997) “The Influence of Company Characteristics and Accounting Regulations on Information Disclosed by Spanish Firms", The European Accounting Review, Vol. 1, No. 1, pp. 45-68.

Raffournier (1995) The Determinants of Voluntary Financial Disclosure by Swiss Listed companies, The European Accounting Review, Vol.4, No 2, pp.261-280.

Wallace (1987) "Disclosure of Accounting Information in Developing Countries: A Case Study of Nigeria", Doctoral Dissertation, University of Exeter, Devon.

\section{ABC-JAR!!!}

"Speedy publication service, Online archives, Paperless, web-based peer review system, Open access policy, Indexing in world known citation

databases, Global circulation, Broad international readership and authorship, Online submission system, Minimum publication charge" 